\title{
OFFSHORE FAULTING IN THE AEGEAN SEA: A SYNTHESIS BASED ON BATHYMETRIC AND SEISMIC PROFILING DATA
}

\author{
Sakellariou D. ${ }^{1}$ and Tsampouraki-Kraounaki K. ${ }^{1}$ \\ ${ }^{1}$ Institute of Oceanography, Hellenic Centre for Marine Research, 19013 Anavyssos, Greece, \\ sakell@hcmr.gr, konstantina.ts.kraounaki@gmail.com
}

\begin{abstract}
Twenty five years after a first attempt by Mascle and Martin (1990), this paper aims at delivering an updated and considerably richer, map of the offshore faults in the Aegean Sea. Reinterpretation of vintage analogue seismic profiles, interpretation of new profiles and records of swath bathymetry data made available in the last two decades, as well as relocation of published faults originally interpreted on lowresolution bathymetric maps, on the new, more accurate bathymetric background have enabled the preparation of a more precise and complete map of active faults occurring in the Aegean Sea. This attempt is a first step towards the creation of an offshore faults database.
\end{abstract}

Keywords: tectonics, vintage/new data, processing, review/reappraisal.

\section{Пєрí $\eta \psi \eta$}

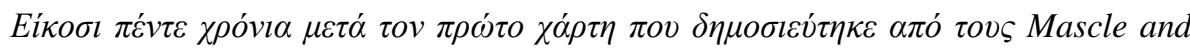

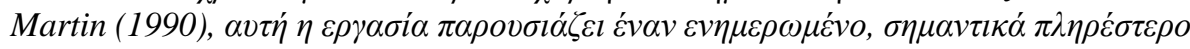

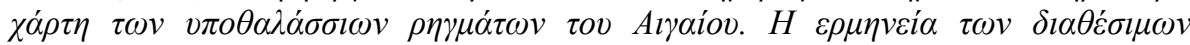

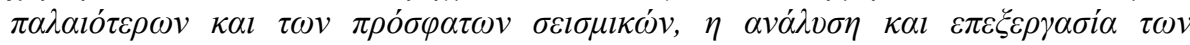

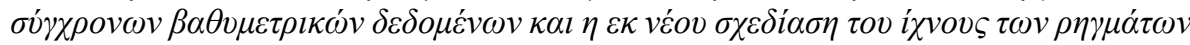

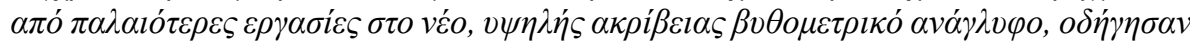

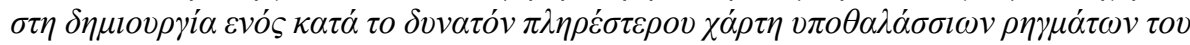

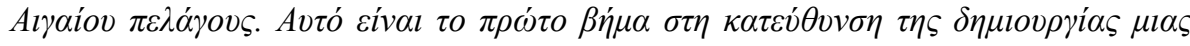

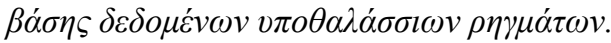

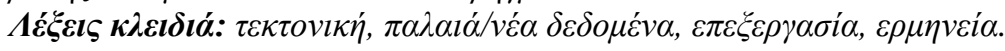

\section{Introduction}

The Aegean Sea has been the subject of extensive research with the aim to better understand its complex geological structure, in particular the active tectonics and deformation pattern, as well as their link to the seismicity. Most of previous studies were based mainly on seismological data and rather poorly mapped faults and fault-zones, low-resolution seafloor bathymetry and GPS data to define the major tectonic elements of the area and interpret its kinematic regime and deformation (McKenzie, 1972, 1978; Le Pichon and Angelier, 1979, 1981; McKenzie and Jackson, 1983; Taymaz et al., 1991; Le Pichon et al., 1995; Davies et al., 1997: Clarke et al., 1998; McClusky et al., 2000; Goldsworthy et al., 2002; Nyst and Thatcher, 2004). Based on widely spaced industrial, multi-channel, seismic reflection profiles, Mascle and Martin (1990), were the first to provide a 
synthesis map of the offshore faults in the Aegean Sea. Since then, only few surveys have been conducted aiming at the systematic mapping and understanding of the offshore fault network.

Twenty five years after the paper of Mascle and Martin (1990), our paper aims at providing a considerably updated map of the offshore fault network in the Aegean Sea; this work is based on swath bathymetry data obtained during the last two decades, interpretation and reinterpretation of recent and former seismic profiles and reinterpretation, on the new, high resolution bathymetry, of the traces of faults mapped in the earlier literature.

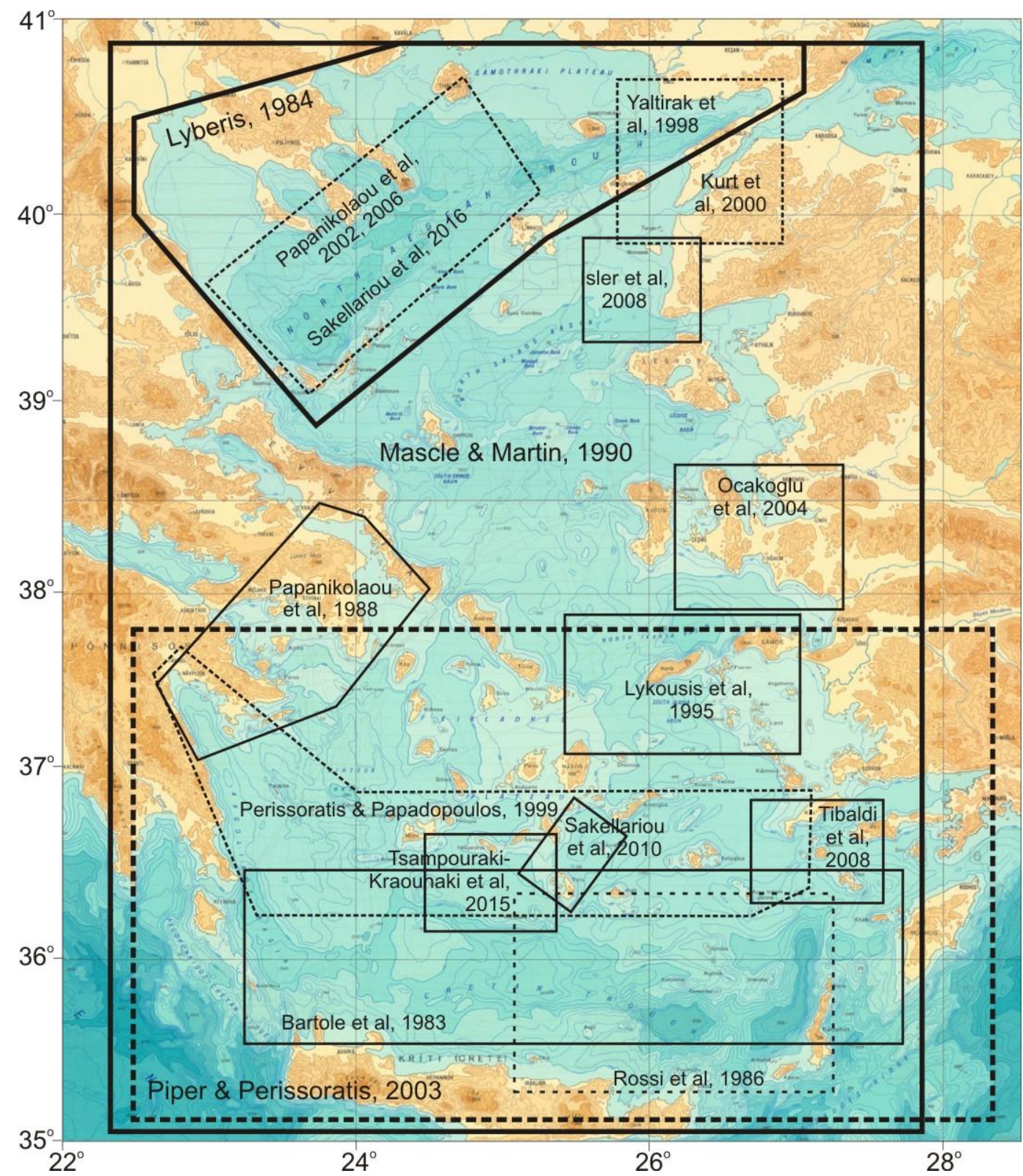

Figure 1 - Location of areas surveyed in the past, contributing to the mapping of offshore faults in the Aegean Sea. 


\subsection{Literature overview (Fig. 1)}

Lyberis (1984) provided a first map of offshore faulting in the North Aegean Trough; this was based on the interpretation of single-beam bathymetry and a few industrial seismic data. Papanikolaou $e t$ al. (2002, 2006), using swath bathymetry and single channel seismic profiles mapped in some detail various faults cutting across the western North Aegean Trough. Yaltirak et al. (1998) and Kurt et al. (2000) provided maps of offshore faults in the Saros Graben, the easternmost area of the North Aegean Trough. Recently, additional swath bathymetry data and seismic profiles from the western North Aegean Trough allowed a reinterpretation and detailed mapping of the fault network (Sakellariou et al., in press).

Apart from the regional synthesis of Mascle and Martin (1990), from the North Aegean Trough to the Cyclades Archipelago, only very few works have contributed to the mapping of offshore faults. Işler et al. (2008) provided a map of the faults off the Turkish coast, north and northwest of Lesvos Island while Lykousis et al. (1995) have published high-resolution seismics in the Ikarian Basin, north and south of Ikaria Island. Onshore faults mapped by Chatzipetros et al. (2013) on Lemnos, Agios Efstratios, Lesvos and Chios Islands allow inferring their offshore prolongation. Ocakoglu et al. $(2004,2005)$ provided new data on faulting for the regions of Izmir Bay and Kusadasi.

Considerably more data and information on offshore faulting are available for the South Aegean Sea. Bartole et al. (1983) and Rossi et al. (1986) surveyed the Cretan Sea and published early tectonic maps of this area. Perissoratis and Papadopoulos (1999) defined the major faults of the area from Argolic Gulf, on the west, over the southern Cyclades Archipelago to the Island of Kos on the East. Papanikolaou et al. (1988) traced the faults of Saronic, Argolic and South Evia Gulfs. Piper and Perissoratis (2003) provided a synthetic map of both, new and previously known, offshore faults in the South Aegean Sea. Swath bathymetry and single channel seismic profiles have been used to map the faults in the area of Nisyros and Kos Islands (Tibaldi et al., 2008; Nomikou and Papanikolaou, 2011), around Santorini (Sakellariou et al., 2010) and in Christiana Basin, between Santorini and Milos Islands (Tsampouraki-Kraounaki et al., 2015).

Recently, the Greek Database of Seismogenic Sources (GreDaSS) has been compiled (Caputo and Pavlides, 2013; Sboras, 2012) as an updatable database and repository of active-fault data for the Greek territory and its surroundings based on geological, tectonic and seismological data.

\section{Materials and Methods}

Our mapping of the offshore faults discussed here is based on the processing and interpretation of literally all available bathymetric and seismic profiling data from the Aegean Sea recorded since the seventies.

The bathymetric relief shown on Fig. 2 includes all swath bathymetry data collected during the last fifteen years, chiefly by the Hellenic Centre for Marine Research. All former and new swath bathymetry data have been reprocessed, GEBCO bathymetry has been used for the areas not surveyed by swath bathymetry, while single beam bathymetry data have been locally used complementary to the GEBCO bathymetry. In the framework of DG MARE EMODNET Bathymetry project (www.emodnet.eu/bathymetry) all available bathymetric data (swath bathymetry, GEBCO, single beam echo-soundings) have been re-processed and gridded to $250 \mathrm{~m}$ cell-size resolutions to create a digital elevation model of the seabed of the Aegean Sea as shown in Fig. 2.

Further processing and analysis of the bathymetric data have included slope analysis in order to better define and highlight steep slopes and visualize their spatial distribution. Steep slopes are commonly associated with, or created, along active faults with significant vertical offset. The map of Fig. 3 shows the distribution of slopes in the Aegean Sea. The slopes are categorized in four groups according to the sloping values $(0-3 \%, 3-5 \%, 5-10 \%$ and $>10 \%)$ aiming at differentiating the steep slopping linear features, which are probably associated with faulting, from the gentler slopping areas. 


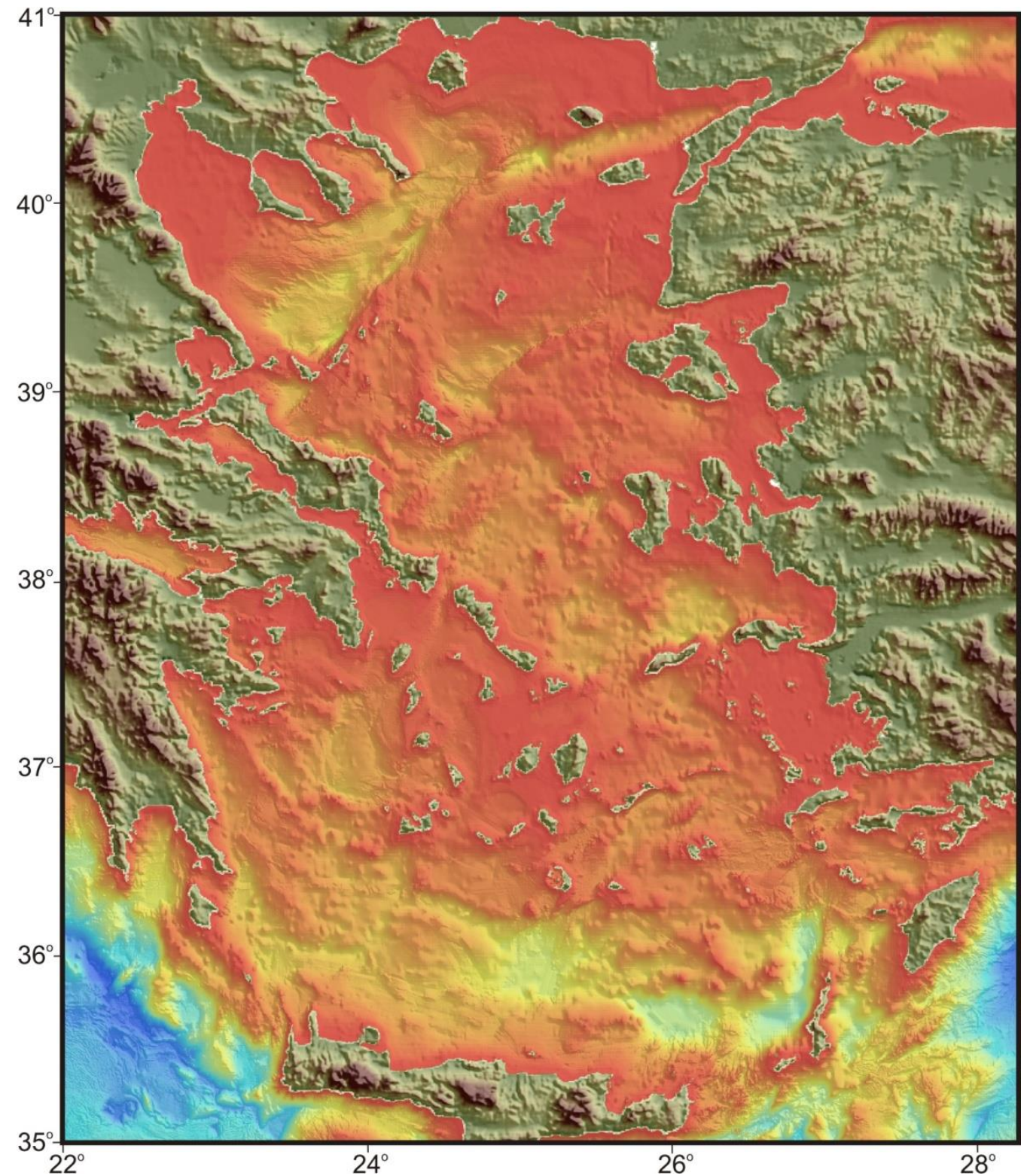

Figure 2 - Digital Elevation Model $(250 \mathrm{~m}$ grid) of the seabed of the Aegean Sea derived from the combination and reprocessing of swath bathymetry, GEBCO and single-beam echosounder data in the framework of DG MARE EMODNET Bathymetry project (www.emodnet.eu/bathymetry).

Old and recent, multi- and single-channel, analogue and digital, high-, moderate- and low-resolution seismic reflection profiles available at HCMR (Fig. 4) have been reprocessed and re-interpreted. The vintage former analogue data have been digitized and many of them transformed into SEG-Y format. Reinterpretation of these profiles under the light of the new knowledge gained over the last decades along with taking advantage of the new high-resolution bathymetric data provided significantly improved localization and better tracing of the faults imaged within them. 
Similar procedure has been used for the recent, digitally acquired, seismic reflection profiles collected by HCMR over the last two decades. Many of them have been re-interpreted, other are still under re-interpretation, in order to extract information on fault location and kinematics.

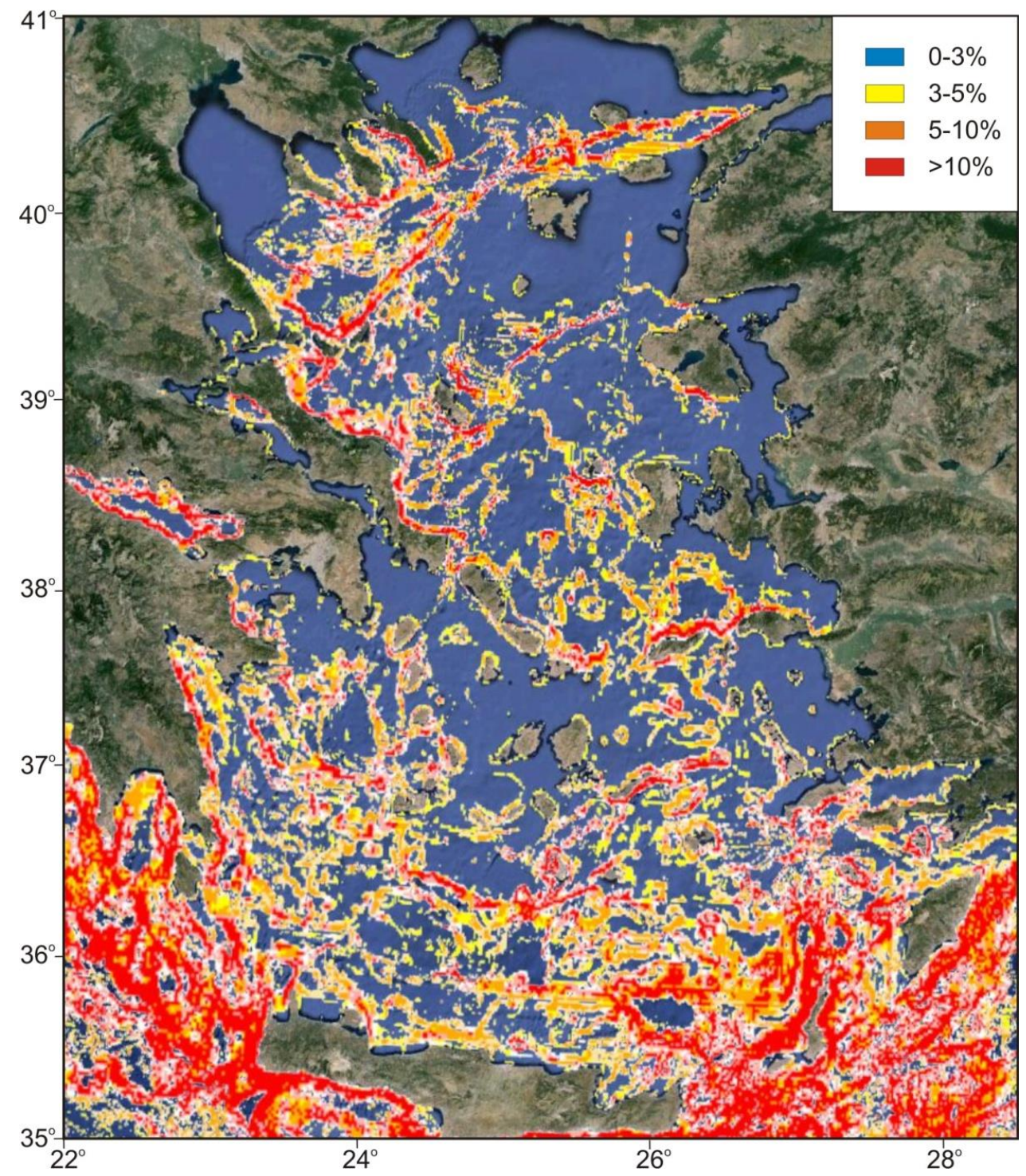

Figure 3 - Slope map of the seabed of the Aegean Sea derived from the slope analysis of the bathymetry shown in Fig. 2.

A significant amount of information on offshore faulting is available in the earlier research papers, as indicated in chapter 1.1. By taking advantage of the currently available, most up-to-date DEM of the Aegean seabed, the tracing of faults extracted from the literature have been re-localized by taking into consideration the seabed morphology, in particular the slopes' orientation, to comply with the seabed's relief.

The area of Santorini - Amorgos Islands has been selected as an example to visualize the methodology we have followed to generate a new map of offshore faults. Figure 5A shows the bathymetric map compiled from swath bathymetry data combined with GEBCO data. 


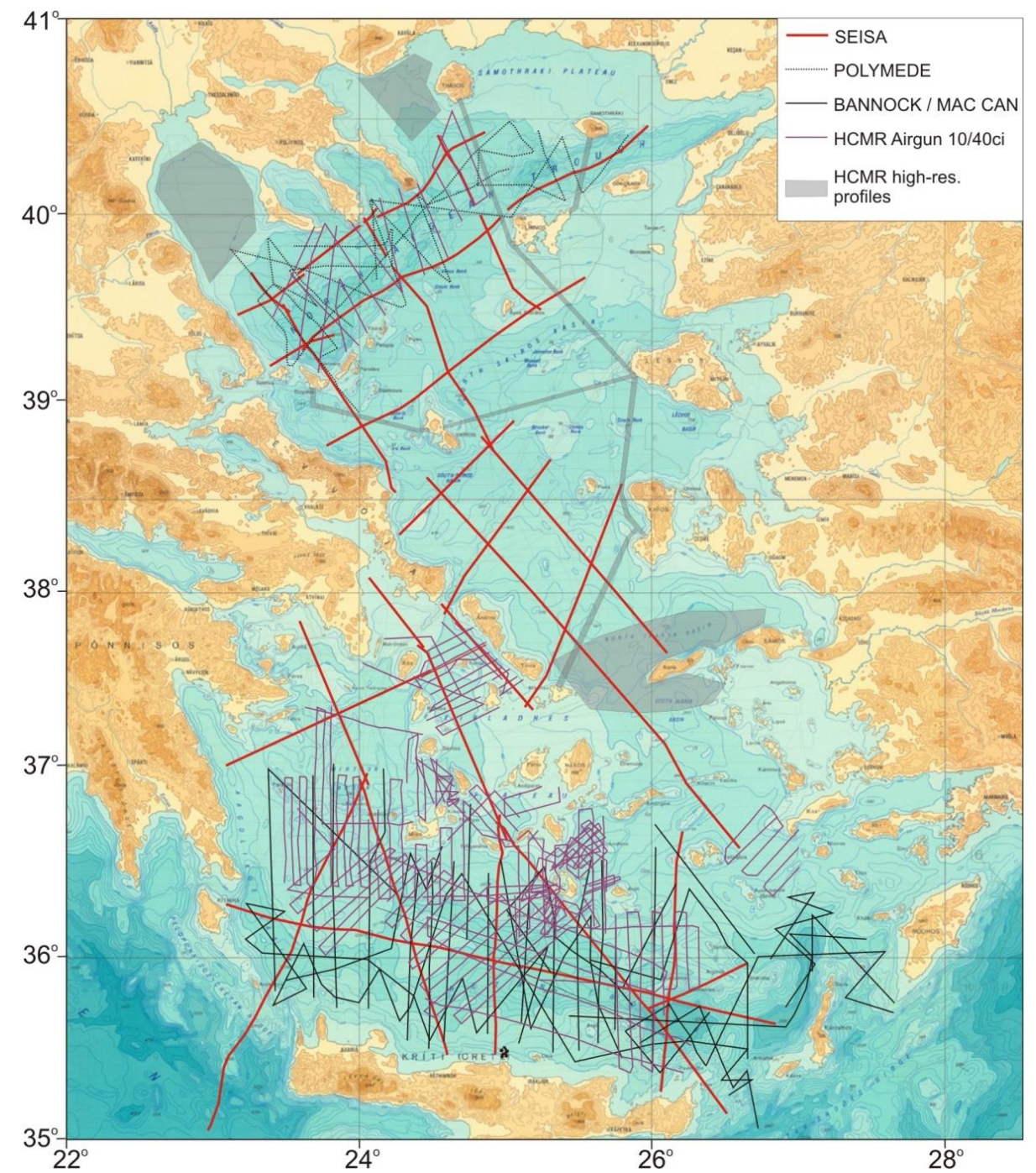

Figure 4 - Location map of multi- and single-channel seismic profiles acquired in the Aegean Sea since the seventies, archived at HCMR.

Reinterpreted SEISA (1974) multi-channel seismic Line 25 (Mascle and Martin, 1990) (Fig. 5B) and interpreted HCMR single channel seismic line (Fig. 5C) are also shown. Faults imaged on the seismic line of Fig. 5B have been located more precisely than initially, on the bathymetric map, using the associated morphological features. Similarly, faults imaged on the seismic line of Fig. 5C, and also mapped on swath bathymetry, can be traced across the boundary to the GEBCO bathymetry. Faults mapped by Perissoratis and Papadopoulos (1999) have also been redrawn on the new bathymetry. The faulting networks as shown on Fig. 5A and based on all available data sets, have been constructed using the same methodology.

The refined map of faults of Santorini-Amorgos area shows two elongate, and clearly tectonically controlled basins, the Anyhdros and Amorgos basins, running parallel to each other in a SW-NE trend and separated from each other by a structural high. The latter connects Anyhdros Island to the westernmost edge of Amorgos Island. Thus, "the Amorgos Fault", believed to have moved during the 1956 earthquake, appears to be a segment of one long fault zone controlling the southeast margin of the Santorini-Anyhdros-Amorgos-Kinairos-Levitha basement ridge. 

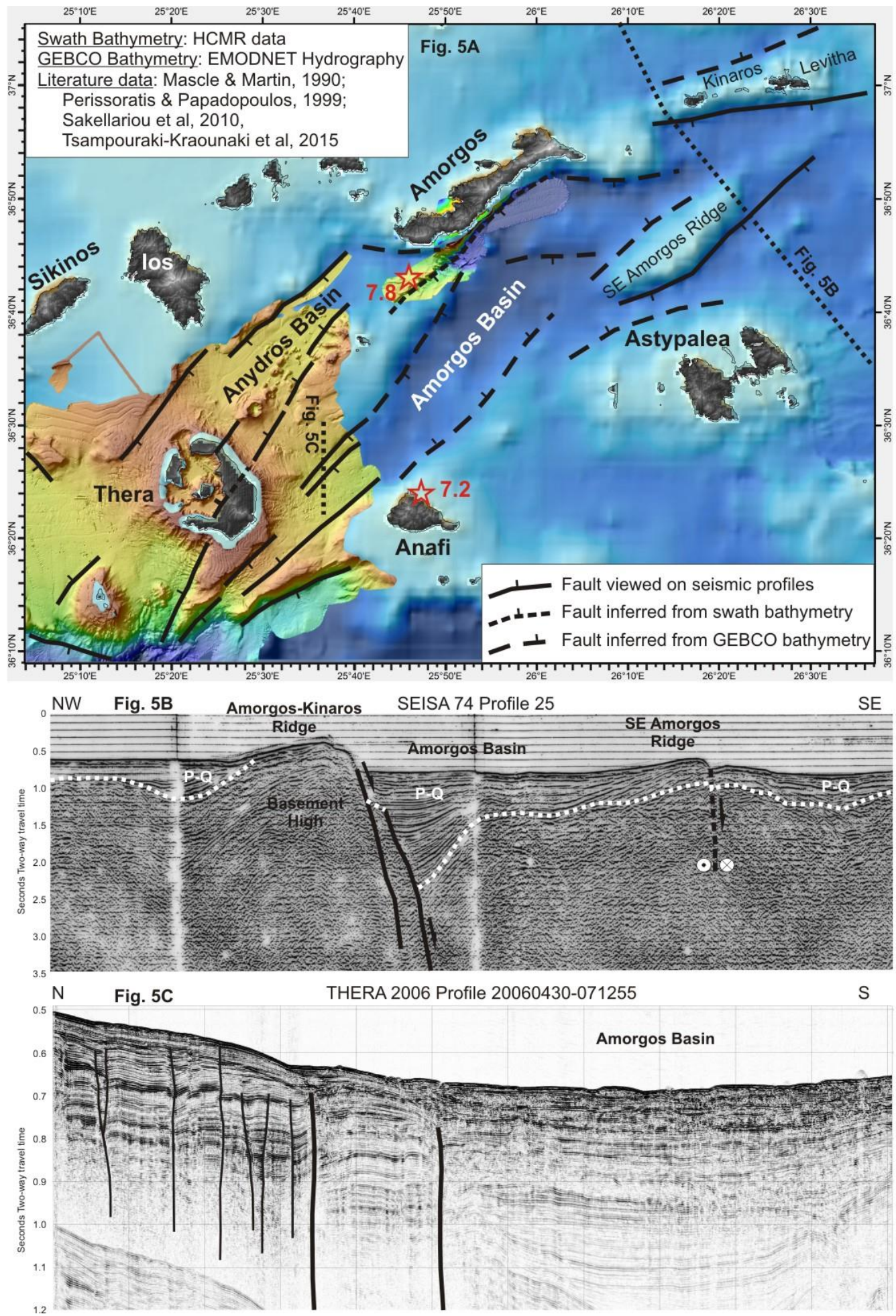

Figure 5 - A: DEM and faults of Santorini-Amorgos area. B: SEISA multi-channel Line 25 (Mascle and Martin, 1990). C: Single channel HCMR profile (Sakellariou et al., 2010). Red stars in $5 \mathrm{~A}$ show the epicenters of the 1956 Amorgos earthquakes. 


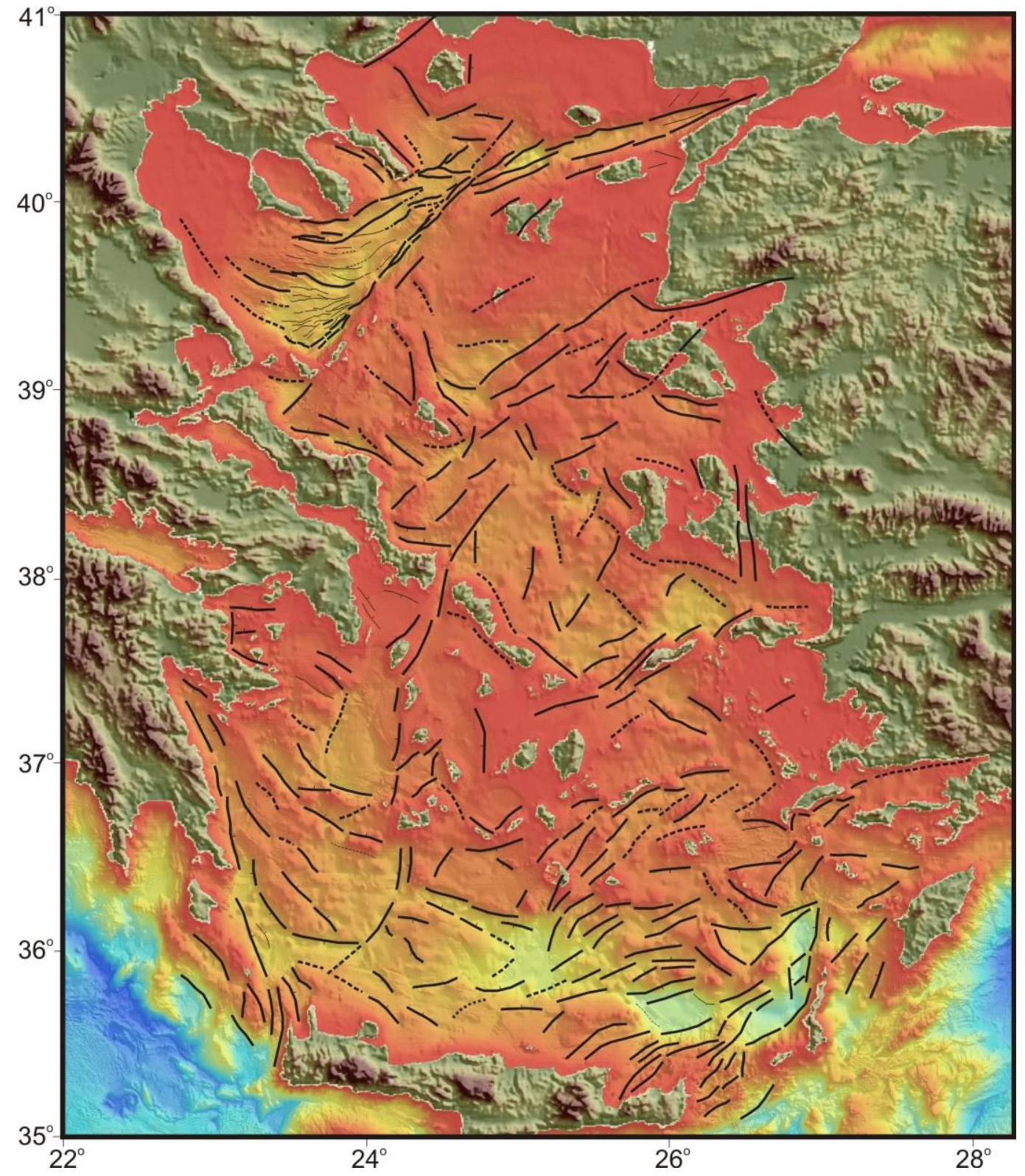

Figure 6 - A: Map of offshore faults of the Aegean Sea derived from the processing and interpretation of bathymetric and seismic profiling data.

\section{Results - Discussion}

The map of the recent and active fault systems of the Aegean Sea (Fig. 6) show the most up-to-date information derived from bathymetric and seismic reflection data available so far. Note that faults derived from seismological data only, are not included in this map. Some areas are better covered in terms of available data, for many others, our confidence in the fault tracing is moderate due to limited data availability. This is the case for example the North Aegean Sea between the North Aegean Trough and the Cyclades Archipelago, the Myrtoon and Karpathian Seas. Other areas have been analysed only in terms of widely spaced seismic profiles. For all these areas it will be necessary to collect new swath bathymetry and seismic profiling data. 
Analysis of the kinematics of the mapped faults is beyond the scope of this paper. The fault-map shown here is a first attempt towards the creation of a GIS-based offshore fault database, which will be continuously updated as soon as new data and information will be available This work aims at complementing earlier and ongoing projects such as the GReDaSS (Caputo and Pavlides, 2013; Sboras, 2012) and others, and will be hopefully linked to them.

\section{Acknowledgments}

This work is partly funded by the DG MARE EMODNET Geology project. We are grateful to our colleagues at HCMR, P. Drakopoulou and Ch. Kyriakidou, for the analysis and processing of the bathymetric data used here. The authors are extremely thankful to Emeritus Professor Jean Mascle. His work has inspired this paper and his continuous support has contributed tremendously to the elaboration of the new fault map of the Aegean Sea. Last but not least, we thank the Captain and the crew of R/V Aegaeo and R/V Alkyon for their tireless support during the numerous cruises in the Aegean Sea, and our colleagues at the Institute of Oceanography of the Hellenic Centre for Marine Research, who contributed to the collection of the data.

\section{References}

Bartole, R., Catani, G., Lenardon, G. and Vinci, A. 1983. Tectonics and sedimentation of the southern Aegean Sea, Boll. Oceanol. Teor. App., 1, 319-340.

Caputo, R. and Pavlides, S., 2013. The Greek Database of Seismogenic Sources (GreDaSS), version 2.0.0: A compilation of potential seismogenic sources $(\mathrm{Mw}>5.5)$ in the Aegean Region. http://gredass.unife.it/, doi: 10.15160/unife/gredass/0200.

Chatzipetros, A., Kiratzi, A., Sboras, S., Zouros, N. and Pavlides, S., 2013. Active faulting in the north-eastern Aegean Sea Islands, Tectonophysics, 597-598, 106-122.

Clarke, P.J., Davies, R.R., England, P.C, Parsons, B., Billiris, H., Paradissis, D., Veis, G., Cross, P.A., Denys, P.H., Ashkenazi, V., Bingley, R., Kahle, H.-G., Muller, M.-V. and Briole, P., 1998. Crustal strain in central Greece from repeated GPS measurements in the interval 19891997, Geophys. J. Int., 135, 195-214.

Davies, R., England, P., Parsons, B., Billiris, H., Paradissis, D. and Veis, G., 1997. Geodetic strain of Greece in the interval 1892-1992, J. Geophys. Res., 102, 24,571-4,588.

Goldsworthy, M., Jackson, J. and Haines, J., 2002. The continuity of active faults in Greece, Geophys. J. Int., 148, 596-618.

Işler, E.B., Aksu, A.E., Yaltırak, C. and Hiscott, R.N., 2008. Seismic stratigraphy and Quaternary sedimentary history of the northeast Aegean Sea, Marine Geology, 254, 1-17.

Kurt, H., Demirbag, E. and Kuşçu, I., 2000. Active submarine tectonism and formation of the Gulf of Saros, Northeast Aegean Sea, inferred from multi-channel seismic reflection data, Marine Geology, 165, 13-26.

Le Pichon, X. and Angelier, J., 1979. The Hellenic Arc and trench system: A key to the neotectonic evolution of the eastern Mediterranean area, Tectonophysics, 60, 1-42.

Le Pichon, X. and Angelier, J., 1981. The Aegean Sea, Philos. Trans. R. Soc. London, Ser. A, 300, 357- 372.

Le Pichon, X., Chamot-Rooke, N., Lallemant, S., Noomen, R. and Veis, G., 1995. Geodetic determination of the kinematics of central Greece with respect to Europe, J. Geophys. Res., 100, 12,675-12,690.

Lyberis, N., 1984. Tectonic evolution of the North Aegean Trough, In: The Geological Evolution of the Eastern Mediterranean, Spec. Publ. Geol. Soc., 17, 709-725.

Lykousis, V., Anagnostou, C., Pavlakis, P., Rousakis, G. and Alexandri, M., 1995. Quaternary sedimentary history and neotectonic evolution of the eastern part of the Central Aegean Sea, Greece, Marine Geology, 128, 59-71.

Mascle, J. and Martin, L., 1990. Shallow structure and recent evolution of the Aegean Sea: A synthesis based on continuous reflection profiles, Marine Geology, 94, 271-299.

McClusky, S., Balassanian, S., Barka, A., Demir, C., Ergintav, S., Georgiev, I., Gurkan, O., Hamburger, M., Hurst, K., Kahle, H., Kastens, K., Kekelidze, G., King, R., Kotzev, V., Lenk, 
O., Mahmoud, S., Mishin, A., Nadariya, M., Ouzounis, A., Paradissis, D., Peter, Y., Prilepin, M., Reilinger, R., Sanli, I., Seeger, H., Tealeb, A., Toksöz, M.N. and Veis, G., 2000. Global Positioning System constraints on plate kinematics and dynamics in the eastern Mediterranean and Caucasus, J. Geophys. Res., 105, 5695-5719.

McKenzie, D.P., 1972. Active tectonics of the Mediterranean region, Geophys. J. R. Astron. Soc., 30, 109-185.

McKenzie, D.P., 1978. Active tectonics of the Alpine Himalayan Belt, the Aegean Sea and surrounding regions, Geophys. J. R. Astron. Soc., 55, 217-252.

McKenzie, D.P. and Jackson, J.A., 1983. The relationship between strain rates, crustal thickening, paleomagnetism, finite strain and fault movements within a deforming zone, Earth \& Planet. Sci. Lett., 65, 182-202.

Nomikou, P. and Papanikolaou, D., 2011. Extension of active fault zones on Nisyros volcano across the Yali-Nisyros Channel based on onshore and offshore data, Mar Geophys Res, doi: 10.1007/s11001-011-9119-z.

Nyst, M. and Thatcher, W., 2004. New constraints on the active tectonic deformation of the Aegean, J. Geoph. Res., 109, B11406, doi: 10.1029/2003JB002830, 2004.

Ocakoglu, N., Demirbag, E. and Kuşçu, I., 2004. Neotectonic structures in the area offshore of Alacati, Doganbey and Kusadasi (western Turkey): evidence of strike-slip faulting in the Aegean extensional province, Tectonophysics, 391, 67-83.

Ocakoglu, N., Demirbag, E. and Kuşçu, I., 2005. Neotectonic structures in Izmir Gulf and surrounding regions (western Turkey): Evidences of strike-slip faulting with compression in the Aegean extensional regime, Marine Geology, 219, 155-171.

Papanikolaou, D., Lykousis, V., Chronis, G. and Pavlakis, P., 1988. A comparative study of neotectonic basins across the Hellenic arc: the Messiniakos, Argolikos, Saronikos and Southern Evoikos Gulfs, Basin Research, 1, 167-176.

Papanikolaou, D., Alexandri, M., Nomikou, P. and Ballas, D., 2002. Morphotectonic structure of the western part of the North Aegean Basin based on swath bathymetry, Marine Geology, 190, 465-492.

Papanikolaou, D., Alexandri, M. and Nomikou, P., 2006. Active faulting in the north Aegean basin, Geol. Soc. America, Sp. Paper 409, 189-209, doi: 10.1130/2006. 2409(11).

Ptis, C. and Papadopoulos, G.A., 1999. Sediment instability and slumping in the southern Aegean Sea and the case history of the 1956 tsunami, Marine Geology, 161, 287-305.

Piper, D.J.W. and Perissoratis, C., 2003. Quaternary neotectonics of the South Aegean arc, Marine Geology, 198, 259-288.

Rossi, S., Got, H., Taviani, M. and Martin, L., 1986. Elements structuraux de la mer de Crete orientale et du Golfe d'Antalya (Mediterranee orientale), Mem. Soc. Geol. It., 36, 153-164

Sakellariou, D., Sigurdsson, H., Alexandri, M., Carey, S., Rousakis, G., Nomikou, P., Georgiou, P. and Ballas, D., 2010. Active tectonics in the Hellenic Volcanic Arc: the Kolumbo submarine volcanic zone, Bulletin of the Geological Society of Greece, XLIII/2, 1056-1063.

Sakellariou, D., Rousakis, G., Vougioukalakis, G., Ioakim, Ch., Panagiotopoulos, I., Morfis, I., Zimianitis, E., Athanasoulis, K., Tsampouraki-Kraounaki, K., Mpardis, D. and Karageorgis, A.P., 2016. Deformation pattern in the Western North Aegean Trough: Preliminary results, Proceedings of the $14^{\text {th }}$ Intern. Conference, Thessaloniki, May 2016.

Sboras, S., 2012. The Greek Database of Seismogenic Sources: seismotectonic implications for North Greece, PhD Thesis, University of Ferrara, Ferrara, 252 pp.

Taymaz, T., Jackson, J.A. and McKenzie, D., 1991. Active tectonics of the north and central Aegean Sea, Geophys. J. Int., 106, 433-490.

Tibaldi, A., Pasquare, F.A., Papanikolaou, D. and Nomikou, P., 2008. Tectonics of Nisyros Island, Greece, by field and offshore data, and analogue modelling, Journal of Structural Geology 30, 1489-150.

Tsampouraki-Kraounaki, K., Sakellariou, D., Anastasakis, G. and Tripsanas, E., 2015. Shallow structure and seismic stratigraphy of Christiana Basin, South Aegean Sea, Proceedings 11th Hell. Symp. Oceanography \& Fisheries, Lesvos, Greece, May 2015, 989-992.

Yaltırak, C., Alpar, B. and Yüce, H., 1998.Tectonic elements controlling the evolution of the Gulf of Saros (northeastern Aegean Sea, Turkey), Tectonophysics, 300, 227-248. 